\title{
Characterization of Insulin-Like Growth Factor Binding Protein-3 in Chronic Renal Failure Serum
}

\author{
DAVID R. POWELL. FRANCIS LIU, BONITA BAKER. PHILLIP D. K. LEE. CRAIG W. BELSHA. \\ EILEEN D. BREWER. AND RAYMOND L. HINTZ \\ Departme'm of Pediatrics, Baylor College' of Medicine, Houston. Texas 77030 /D.R.P.. P.D.K.L., C. W.B., E.D.B./: \\ and the Department of Pediatrics. Stanford University Medical Center. \\ Stanford. California 94305 /F.L., B.B., R.L.H.]
}

\begin{abstract}
IGF-binding protein-3 (IGFBP-3), usually found as glycosylated 41- and 38-kD forms, is the major serum IGFBP during extrauterine life. In normal serum IGFBP-3 binds one IGF peptide and one acid-labile $(\alpha)$ subunit in a high-molecular-weight (MW) complex of 150 kD. By RIA, an excess of IGFBP-3 is present in chronic renal failure (CRF) serum, where it reportedly accumulates at low MW (25-55 kD) rather than as part of the 150-kD complex. To further evaluate IGFBP-3 forms in CRF, sera were obtained from seven healthy adolescents and seven adolescents with CRF. By RIA, IGFBP-3 levels were higher in CRF than normal sera $(15.4 \pm 2.2$ versus $10.1 \pm$ $2.1 \mu \mathrm{g} / \mathrm{mL})$. High-MW (150-kD) fractions of CRF and normal sera, obtained by neutral size-exclusion chromatography, had equal amounts of IGFBP-3 by RIA. However, a second RIA peak of IGFBP-3, present in low-MW (35kD) fractions of CRF but not normal sera, could account for the higher IGFBP-3 levels of CRF serum. [ ${ }^{125}$ I]IGF ligand blots of whole serum and serum fractions, either with or without prior precipitation by IGFBP-3 antiserum, found levels of 41- and 38-kD IGFBP-3 forms to be similar between CRF and normal whole sera and located these forms in the high-MW (150-kD) fractions of CRF and normal sera. $\mid{ }^{125}$ I]IGF ligand blots also identified excess IGFBP in low-MW CRF serum fractions; cross-linking these IGFBP with [ ${ }^{125}$ I]IGF-I, followed by precipitation with IGFBP-1, -2 , and -3 antibodies, identified high levels of unsaturated IGFBP-1, IGFBP-2, and 19- and 14-kD forms of IGFBP-3 in CRF serum. These studies indicate that 1) normal levels of functional 41- and 38-kD IGFBP3 forms are present in CRF serum, and these forms can be incorporated into the 150-kD serum complex; and 2) high RIA levels of IGFBP-3 in low-MW fractions of CRF serum are at least in part due to 19- and 14-kD IGFBP-3 forms. These studies suggest that the excess unsaturated IGFBP of CRF serum are small enough to enter interstitial tissue spaces where they may modulate IGF-I-mediated mitogenic, metabolic, and differentiative effects. (Pediatr Res 33: 136-143, 1993)
\end{abstract}

\section{Abbreviations}

IGFBP, IGF-binding protein

MW, molecular weight

CRF, chronic renal failure

Received April 7, 1992: accepted September 21. 1992.

Correspondence and reprint requests: Dr. David R. Powell. Texas Children's Hospital. Clinical Care Center. Suite 800. MC \#3-2482. 6621 Fannin St.. Houston. TX 77030.

Supported by NIH Grants DK-38773 (to D.R.P.) and DK-24085 (to R.L.H.) and a feasibility grant from the American Diabetes Association (to P.D.K.L.).
IGF-I and -II are peptides that promote the growth and differentiated function of many tissues (1-3). These 7.5-kD peptides are found in serum and other body fluids at a higher MW. tightly bound by a family of at least six IGFBP (4-10). Most IGF circulate at $\sim 150 \mathrm{kD}$ (high-MW serum fractions) in association with a $41-$ or $38-\mathrm{kD}$ form of IGFBP-3 and an acid-labile $(\alpha)$ subunit (10-12), whereas the remaining IGF circulate at $\sim 35 \mathrm{kD}$ (low-MW serum fractions) bound to some or all of the six IGFBP. Because IGFBP in the low-MW fractions are in molar excess of IGF, they provide unsaturated sites for IGF binding $(10,13)$.

The 41- and 38-kD forms of intact, differentially glycosylated IGFBP-3 are the major serum IGFBP during extrauterine life. Levels of these two IGFBP-3 forms, and also of the 150-kD complex, seem to vary directly with the GH status of the individual $(10,14)$. This suggests an anabolic role for the $41-$ and 38-kD IGFBP-3 forms, perhaps as part of this $150-\mathrm{kD}$ complex. In fact, these 41 - and 38-kD IGFBP-3 forms can potentiate IGF action under some, but by no means all, experimental conditions (15-18).

Two additional IGFBP are well characterized. IGFBP-1 and IGFBP-2 are nonglycosylated proteins of 28 and $33 \mathrm{kD}$, respectively. Both migrate in low-MW serum fractions and may contribute significantly to the IGF-binding capacity of serum; this is especially true before puberty, when levels of both proteins are highest $(19,20)$. IGFBP-1 levels and serum IGF-binding capacity are each high during $\mathrm{GH}$ deficiency and fall with $\mathrm{GH}$ therapy: in rats, IGFBP-1 and -2 levels are also high in growth-failure states such as undernutrition and diabetes mellitus, and levels fall in the presence of insulin $(10,13,21-24)$. Such data suggest that IGFBP-1 and -2 may block the anabolic effects of IGF peptides in vivo. In fact, IGFBP-1 and -2 inhibit IGF action under most (25-27), but not all (28), experimental conditions. apparently by competing with IGF receptors for IGF binding $(25,26)$.

The marked growth failure of children with CRF has suggested a need to characterize the IGF system in uremia. As in GH deficiency, CRF is associated with 1 ) a shift of IGF from 150 - to 35-kD serum fractions; 2) higher serum IGFBP-1 levels: and 3) increased capacity of serum to bind IGF peptides $(10,19,29-$ 31). However, CRF differs from GH deficiency in that IGF levels are not low, and IGFBP-3 levels are high, in CRF serum when measured by RIA (10, 19, 30-34). Blum et al. (33) explained this discrepancy by noting that serum IGFBP-3 from CRF children is not present as part of the $150-\mathrm{kD}$ complex, but instead is found as multiple forms in low-MW serum fractions. They hypothesized that the multiple low-MW IGFBP-3 forms are responsible for the increased IGF-binding capacity of CRF 
serum. and that this excess of unsaturated binding sites may inhibit IGF action in vivo, including a possible inhibition of skeletal growth. The significance of an almost complete absence of 150-kD complex was not addressed by Blum et al:; presumably, IGFBP-3 not trapped in the $150-\mathrm{kD}$ complex would more easily enter extravascular spaces to inhibit IGF action.

In past studies, we have also found by RIA that serum IGFBP3 levels are high in CRF children (19). However, we did not find high levels of the 41- and 38-kD IGFBP-3 forms when CRF and normal sera were transferred to nitrocellulose membranes and probed with [ [ $\left.{ }^{125} \mathrm{I}\right] \mathrm{IGF}$, a method known as ligand blotting. Also, further studies using this technique indicated that most of the 41 - and 38-kD IGFBP-3 forms present in the serum of CRF children migrated with the $150-\mathrm{kD}$ serum complex and not at a lower MW (29). The present studies attempted to resolve the above discrepancies by further characterizing the IGFBP-3 forms found in CRF serum.

\section{MATERIALS AND METHODS}

Peptides. Recombinant IGF-I and IGF-II were obtained from Amgen (Thousand Oaks, CA) and from Eli Lilly Co. (Indianapolis, IN), respectively. Recombinant IGFBP-3 was a gift of Biogrowth, Inc. (Richmond, CA). These peptides were iodinated by a modification of the chloramine-T method (20). IGFBP-1 was purified from amniotic fluid and was iodinated as described previously $(19,27)$. $\left[{ }^{125} \mathrm{I}\right] \alpha$-subunit was kindly provided by $\mathrm{Dr}$. R. C. Baxter (Sydney, Australia). In some experiments, [ $\left.{ }^{59} \mathrm{Thr}\right]$ IGF-I labeled with ${ }^{125}$ I ([ $\left.\left.{ }^{125} \mathrm{I}\right] \mathrm{IGF}-\mathrm{I}\right)$ was purchased from Amersham (Arlington Heights, IL).

Serum Samples. The experimental protocol was approved by the Baylor Institutional Review Board; informed consent was obtained from all patients before entry. Serum was obtained from six prepubertal children with $\mathrm{CRF}$ and from six age- and gender-matched prepubertal healthy children; the characteristics of these groups of children have been reported (29). In addition, serum was obtained from seven adolescents with CRF requiring chronic hemodialysis therapy (age $17 \pm 2 y$, mean \pm SD) and from seven age- and gender-matched healthy adolescents (age 16 $\pm 2 \mathrm{y}$ ). All individuals were fasted for at least $3 \mathrm{~h}$ before obtaining serum samples; hemodialysis patients had their blood drawn before a regularly scheduled dialysis treatment. Blood samples were clotted at $22^{\circ} \mathrm{C}$ for 0.5 to $2 \mathrm{~h}$ and centrifuged, and the serum was then stored at $-70^{\circ} \mathrm{C}$ until assay.

Size-exclusion Chromatography. Sephacryl S-300. Pooled serum samples $(0.5 \mathrm{~mL})$, composed of equal aliquots from seven healthy adolescents or from seven adolescents with CRF, were individually chromatographed at $\mathrm{pH} 7.4$ on a $0.9 \times 120 \mathrm{~cm}$ Sephacryl S-300 column as described previously (29). Individual 2-mL column fractions were assayed for IGFBP by ligand blotting, and for IGFBP-1 and IGFBP-3 by specific RIA.

Sephadex $G-50$. IGF in the $2-\mathrm{mL}$ fractions from the Sephacryl S-300 column were separated from IGFBP by acid chromatography as described previously (31) and then assayed by specific RIA for IGF-I and IGF-II.

$P-60$. In experiments characterizing the ability of intact serum IGFBP-3 to form the $150-\mathrm{kD}$ complex, CRF and normal serum pools identical to those described above were separated on a Pharmacia K 25/45 column packed with P-60 (Bio-Rad, Richmond, $\mathrm{CA}$ ). The column was eluted at $22^{\circ} \mathrm{C}$ by running $0.5 \mathrm{M}$ acetic acid, $75 \mathrm{mM} \mathrm{NaCl}$ as mobile phase at $10 \mathrm{~mL} / \mathrm{h}$. Individual $2-\mathrm{mL}$ fractions were collected, and these fractions were then neutralized and assayed for the presence of IGFBP by [ $\left.{ }^{125} \mathrm{I}\right] \mathrm{IGF}$ ligand blot (see method below).

Cross-linking with $\int^{125} I J I G F-I$. Individual CRF and normal serum fractions obtained from the Sephacryl S-300 column were cross-linked to [ $\left.{ }^{125} \mathrm{I}\right] \mathrm{IGF}-\mathrm{I}$ with disuccinimidyl suberate (Pierce Chemical Co., Rockford, IL) as described previously (29). For samples that were cross-linked only, $20 \mu \mathrm{L}$ of the serum fractions were incubated with $40000 \mathrm{cpm}$ of [ $\left.{ }^{125} \mathrm{I}\right] \mathrm{IGF}-\mathrm{I}$ in a total volume of $50-\mu \mathrm{L}$ of $50 \mathrm{mM}$ Tris- $\mathrm{HCl}, \mathrm{pH} \mathrm{7.4}$. For samples which were also immunoprecipitated with anti-IGFBP antibodies, $80 \mu \mathrm{L}$ of the serum fractions were incubated with $80000 \mathrm{cpm}$ of $\left[{ }^{125} \mathrm{I}\right]$ IGF-I in a total volume of $100 \mu \mathrm{L}$. After 3 to $4 \mathrm{~h}$ at $22^{\circ} \mathrm{C}$, crosslinking was begun by adding $1 / 10$ volume of $10 \mathrm{mM}$ disuccinimidyl suberate. After $30 \mathrm{~min}$ at $22^{\circ} \mathrm{C}$, the reaction was quenched by adding $1 / 10$ volume of $1 \mathrm{M}$ Tris- $\mathrm{HCl}, \mathrm{pH} 8.0$, containing 10 mM EDTA. Control samples were kept at $4^{\circ} \mathrm{C}$ overnight and immunoprecipitation samples were incubated with IGFBP antibodies as described below.

Cross-linking with $\left.\right|^{125} I / \alpha$-subunit and $\left.I^{125} I\right] I G F-I / I G F B P-3$. Affinity cross-linking was used to identify the reconstructed 150 $\mathrm{kD}$ serum complex. Some studies used a covalent complex between $\left[{ }^{125} \mathrm{I}\right] \mathrm{IGF}-\mathrm{I}$ and IGFBP-3, which was prepared by incubating $1 \times 10^{7} \mathrm{cpm}\left[{ }^{125} \mathrm{I}\right] \mathrm{IGF}-\mathrm{I}$ with $0.5 \mu \mathrm{g}$ IGFBP-3 under the cross-linking conditions described above. The cross-linked $\left[{ }^{125} \mathrm{I}\right]$ IGF-I/IGFBP-3 complex was purified by gel filtration on Sephadex G-75, using $0.5 \mathrm{M}$ acetic acid, $75 \mathrm{mM} \mathrm{NaCl}, 0.25 \% \mathrm{BSA}$ (Sigma Chemical Co., St. Louis, MO), pH 3.0, as mobile phase. All studies designed to reconstruct the $150-\mathrm{kD}$ complex used $30000-40000 \mathrm{cpm}$ of either $\left[{ }^{125} \mathrm{I}\right] \alpha$-subunit or $\left[{ }^{125} \mathrm{I}\right] \mathrm{IGF}-\mathrm{I} /$ IGFBP-3 and the cross-linking conditions above. In experiments using [ ${ }^{125}$ I]IGF-I/IGFBP-3, this radioligand was incubated with $2 \mu \mathrm{L}$ whole serum. In experiments using $\left[{ }^{125} \mathrm{I}\right] \alpha$-subunit, this radioligand was incubated with I) $50 \mathrm{ng}$ purified IGF-I and either 50 or $100 \mathrm{ng}$ purified IGFBP-3;2) $2 \mu \mathrm{L}$ whole serum; 3) $20 \mu \mathrm{L}$ Sephacryl S-300 serum fractions; or 4) $100 \mathrm{ng}$ pure IGF-I and $20 \mu \mathrm{L}$ of serum fractions from the acid P-60 column.

Samples affinity cross-linked with $\left[{ }^{125} \mathrm{I}\right] \mathrm{IGF}-\mathrm{I} / \mathrm{IGFBP}-3$ were separated by SDS-PAGE under nonreducing conditions on a 5 to $15 \%$ gradient gel. Samples affinity cross-linked with $\left[{ }^{125} \mathrm{I}\right] \alpha-$ subunit were reduced by addition of $1 / 4$ volume $4 \times$ sample buffer containing $5 \% \beta$-mercaptoethanol followed by boiling for $5 \mathrm{~min}$; these samples were then separated by SDS-PAGE.

Immunoprecipitation. MAb against human IGFBP-1 was a gift of Dr. E. M. Rutanen (Helsinki, Finland) (35). Antiserum against rat IGFBP-2 (3695) was a gift of Dr. M. M. Rechler (Bethesda, MD) (36). Antiserum against human IGFBP-3 was a gift of Dr. W. F. Blum (Tubingen, Germany) (37). These three antibodies were used to immunoprecipitate IGFBP directly from serum and serum fractions, and also to immunoprecipitate IGFBP from these sources that had first been cross-linked to [ $\left.{ }^{125} \mathrm{I}\right] \mathrm{IGF}-\mathrm{I}$ as described previously (20). Briefly, Staphylococcus protein-A (Pansorbin, Calbiochem, LaJolla, CA) was washed in $50 \mathrm{mM}$ Tris- $\mathrm{HCl}, \mathrm{pH} \mathrm{7.4}$, and resuspended in the original volume with Tris buffer. Nonspecific precipitation by Pansorbin was eliminated by preincubating samples with $50 \mu \mathrm{L}$ Pansorbin for $2 \mathrm{~h}$ at $4^{\circ} \mathrm{C}$ on a rotating mixer; the Pansorbin was then removed by centrifugation.

For each immunoprecipitation, $50 \mu \mathrm{L}$ Pansorbin were incubated for $4 \mathrm{~h}$ at $4^{\circ} \mathrm{C}$ with $1 \mu \mathrm{L}$ IGFBP-3 antiserum, $5 \mu \mathrm{L}$ IGFBP2 antiserum or $5 \mu$ L IGFBP-1 MAb; Pansorbin used with IGFBP1 antibody was first coated with rabbit anti-mouse $\operatorname{IgG}$ (Organon Teknika Corp., West Chester, PA). After centrifugation, the antibody-Pansorbin pellets were washed, resuspended, and incubated with the prepared samples overnight at $4^{\circ} \mathrm{C}$ on a rotating mixer. Immunoprecipitates were pelleted by centrifugation and washed three times with $50 \mathrm{mM}$ Tris- $\mathrm{HCl}, \mathrm{pH} \mathrm{7.4,} \mathrm{containing}$ $0.5 \%$ Triton X-100. Samples to be used in [ $\left.{ }^{125} \mathrm{I}\right] \mathrm{IGF}$ ligand blots were resuspended in $75 \mu \mathrm{L}$ nonreducing sample buffer, and crosslinked samples were resuspended in the same buffer containing $5 \% \beta$-mercaptoethanol. After boiling for $5 \mathrm{~min}$, samples were centrifuged and their supernatants then electrophoresed on a $12 \%$ polyacrylamide gel.

$\int^{125} I J I G F$ ligand blotting. [ $\left.{ }^{125} \mathrm{I}\right] \mathrm{IGF}$ ligand blotting was performed as described previously (29) and is based on the method originally described by Hossenlopp et al. (38). Briefly, serum. serum fractions, and immunoprecipitated IGFBP were electrophoresed on a $12 \%$ SDS polyacrylamide gel under nonreducing conditions. Separated proteins were transferred to nitrocellulose 
(0.45- $\mu \mathrm{m}$ pore size), using a Biotrans semidry electrophoretic transfer unit (Gelman Sciences, Ann Arbor, MI) and Towbin buffer ( $25 \mathrm{mM}$ Tris/192 mM glycine/20\% methanol). Nitrocellulose membranes were blocked in succession with $3 \%$ Nonidet P-40 (Sigma). 1\% BSA (Sigma), and 0.1\% Tween-20 (Sigma) in Tris-saline, $\mathrm{pH} 7.4$, and then incubated overnight with approximately $2 \times 10^{6} \mathrm{cpm}\left[{ }^{125} \mathrm{I}\right] \mathrm{IGF}-\mathrm{I}$ or $2 \times 10^{6} \mathrm{cpm}\left[{ }^{125} \mathrm{I}\right] \mathrm{IGF}-\mathrm{II}$. After washing and drying, filters were exposed to film for 1 to 3 d.

$R I A$. For IGF-I and IGF-II RIA, individual serum fractions were acid chromatographed to separate IGF from IGFBP; after acid chromatography, the fractions containing IGF were pooled, lyophilized, reconstituted, and assayed as described previously (20). IGF-I antiserum was provided by Drs. L. E. Underwood and J. J. Van Wyk (Chapel Hill, NC) through the National Hormone and Pituitary Program. IGF-II antibody was purchased from Amano International Enzyme Co. (Troy, VA).

IGFBP- 1 and IGFBP-3 levels were measured directly in serum and serum fractions. The IGFBP-3 RIA was performed as described previously (20), using the same antiserum as was used for immunoprecipitation; radioligand consisted of $\left[{ }^{125} \mathrm{I}\right] \mathrm{IGF}-\mathrm{I}$ covalently bound to IGFBP-3 (34). The IGFBP-1 RIA was also performed as described previously, using antiserum raised to human IGFBP-1 purified from human HEP G2 cells (19).

\section{RESULTS}

$\int^{125} J$ IGF Ligand Blotting of Whole-Serum Samples. Individual sera from age-matched CRF and normal children and pooled CRF and normal sera from these same children were compared by [ ${ }^{125}$ I]IGF-I ligand blot. As shown in Figure 1, 41- and 38-kD IGFBP-3 forms were present in sera of CRF children throughout the prepubertal years, and in general these levels were not different from levels present in the sera of normal children. In contrast, levels of a 33-kD IGFBP and a 28-kD IGFBP were elevated in CRF sera. Also, CRF sera usually had a diffuse region of $\left[{ }^{125} \mathrm{I}\right]$ IGF-I binding between 28 and $22 \mathrm{kD}$.

Similar studies were performed on sera from seven adolescents with CRF and seven age-matched controls, using [ $\left.{ }^{125} \mathrm{I}\right] \mathrm{IGF}-\mathrm{II}$ as ligand. As shown in Figure 2, adolescents with CRF show the same pattern of serum IGFBP as do children with CRF. Ligand blotting of adolescent serum samples with [ ${ }^{125}$ I]IGF-I gave similar results to those obtained with [ ${ }^{125}$ I]IGF-II (data not presented).

Immunoprecipitation of IGFBP from Whole-Serum Samples. To identify some of these IGFBP, sera were separately pooled from the seven CRF and seven normal adolescents and subjected to immunoprecipitation using antisera to human IGFBP-3, human IGFBP-1, and rat IGFBP-2. As shown in Figure 3, IGFBP-

\section{kD}

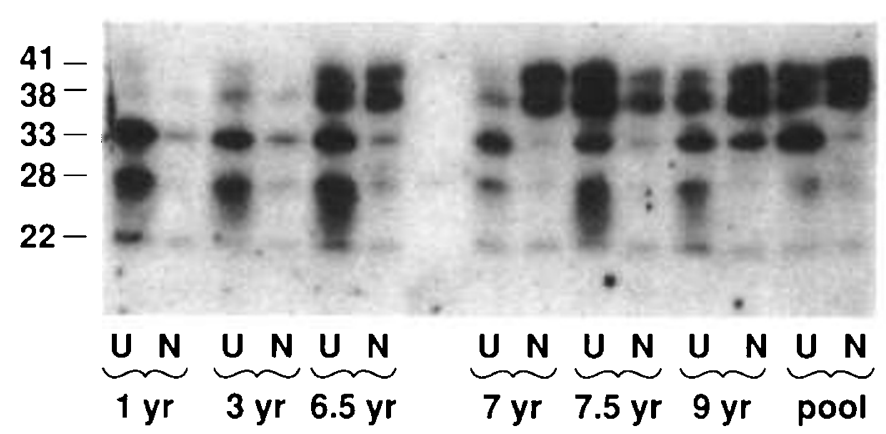

Fig. 1. Ligand blot comparing serum IGFBP levels between six prepubertal children with normal renal function $(N)$ and six prepubertal children with $\mathrm{CRF}$ or uremia $(U)$. Sera $(2 \mu \mathrm{L})$ were separated by nonreducing SDS-PAGE on a $12 \%$ gel, followed by [ $\left.{ }^{125} \mathrm{I}\right] \mathrm{IGF}-\mathrm{I}$ ligand blotting. Size of IGFBP, in kD, is indicated on the left. Age. in y of the age- and gender-matched children is indicated below the blot, as are the paired samples pooled from all six normal and CRF children.

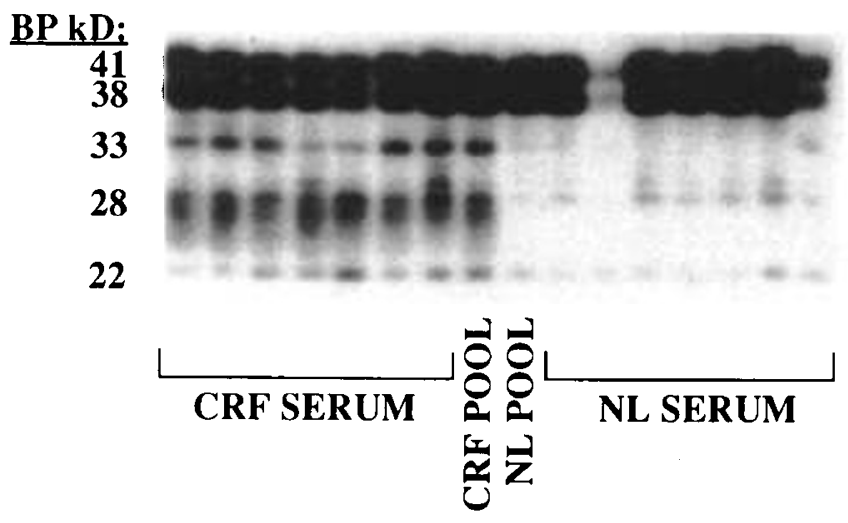

Fig. 2. [ $\left.{ }^{125} \mathrm{I}\right] \mathrm{IGF}-1 \mathrm{l}$ ligand blot comparing serum IGFBP levels between seven adolescents with CRF and seven age- and gender-matched normal $(N L)$ adolescents. Serum samples $(2 \mu \mathrm{L})$ were separated by nonreducing SDS-PAGE on a $12 \%$ gel, followed by ligand blotting with $\left[{ }^{125}\right.$ I]IGF-II used as probe. Size of IGFBP, in $\mathrm{kD}$, is indicated on the left.

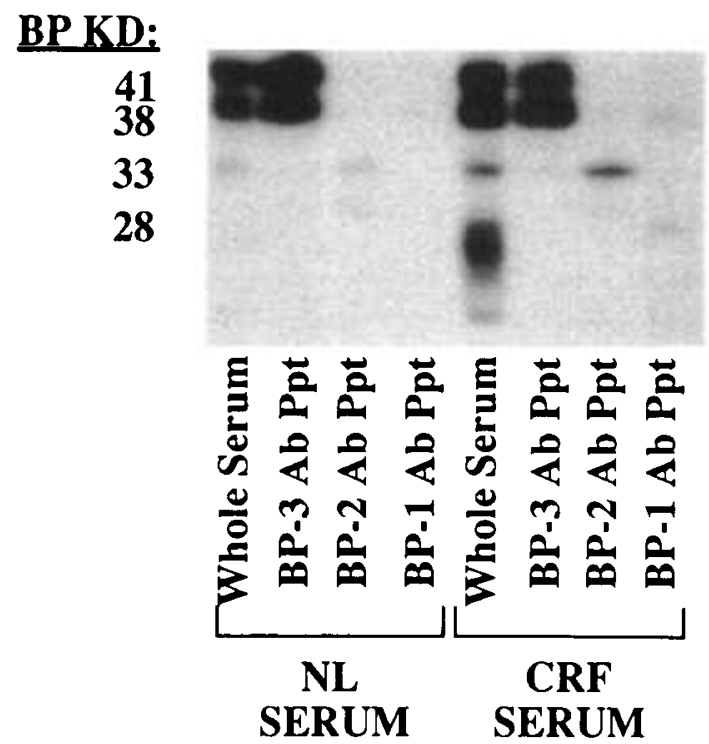

Fig. 3. Immunoprecipitation of normal and CRF sera with specific IGFBP antibodies. Five $\mu \mathrm{L}$ of serum pooled from either the seven normal $(N L)$ adolescents or the seven adolescents with CRF were precipitated by specific antibodies to lGFBP-3 $(B P-3 A h P p t)$. IGFBP-2 $(B P-2 A h$ $P p t)$ and IGFBP-1 (BP-I $A h P p t)$. The immunoprecipitates, and $2 \mu \mathrm{L}$ of each unprecipitated whole serum pool, were then separated by $12 \%$ SDSPAGE under nonreducing conditions and analyzed by ligand blotting using $\left[{ }^{125} \mathrm{I}\right] \mathrm{IGF}-\mathrm{II}$ as probe. $B P$. binding protein.

3 antiserum precipitated only the $41-$ and $38-k D$ IGFBP, and equal amounts of these bands were precipitated from CRF and normal serum. In contrast, the IGFBP-2 antiserum precipitated primarily the $33-\mathrm{kD}$ IGFBP, and more of this band was precipitated from CRF than from normal serum. The IGFBP-1 antiserum precipitated primarily a 28-kD IGFBP from CRF serum, whereas none of this, or any other, IGFBP was precipitated from normal serum. Sera from the 14 adolescents were used in all remaining studies to avoid the age-related variability in IGF and IGFBP levels found in prepubertal populations.

RIA of IGFBP Levels in Whole Serum. Although IGFBP-3 levels were not elevated in CRF serum by ligand blot, levels were significantly higher in CRF serum when measured by RIA; Table 1 shows that IGFBP-3 levels in CRF sera were $\sim 50 \%$ higher than normal. RIA of pooled sera also found a $\sim 50 \%$ increase in CRF $(15.6 \mu \mathrm{g} / \mathrm{mL})$ over normal $(9.3 \mu \mathrm{g} / \mathrm{mL})$ levels, suggesting the pools to be representative of the two groups. IGFBP-1 levels by RIA were also quite elevated in sera from adolescents with CRF. $\int^{125}$ IJIGF Ligand Blotting of Size-Fractionated Serum. To in- 
Table 1. Levels of IGFBP-3 and IGFBP-I measured by specific RIA in sera of normal adolescents and adolescents with $C R F^{*}$

\begin{tabular}{lcc}
\hline & IGFBP-3 $(\mathrm{ng} / \mathrm{mL})$ & IGFBP-1 $(\mathrm{ng} / \mathrm{mL})$ \\
\hline CRF & $15400 \pm 2200 \dagger$ & $262 \pm 247 \ddagger$ \\
Normal & $10100 \pm 2100$ & $13 \pm 14$ \\
\hline
\end{tabular}

* Data are presented as mean $\pm \mathrm{SD}$.

$\dagger$ CRF different from normal, $p<0.05$, by analysis of variance.

$\ddagger$ CRF different from normal, $p<0.05$, by Mann-Whitney two-sample rank testing.

\section{NL SERUM}

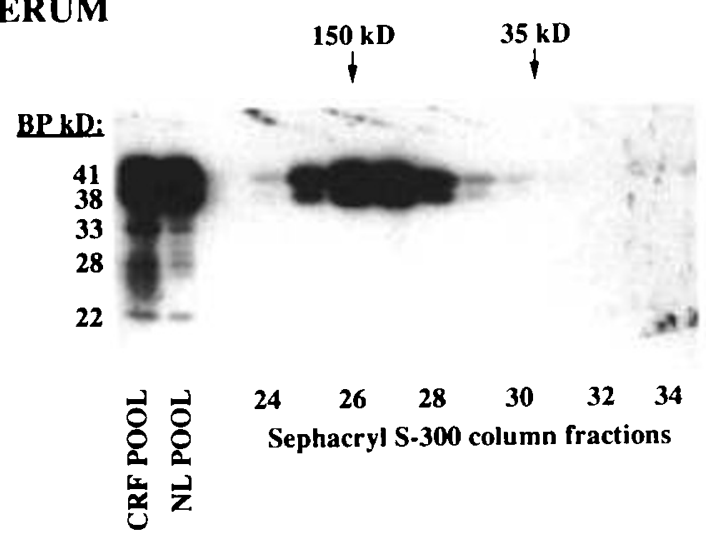

\section{CRF SERUM}

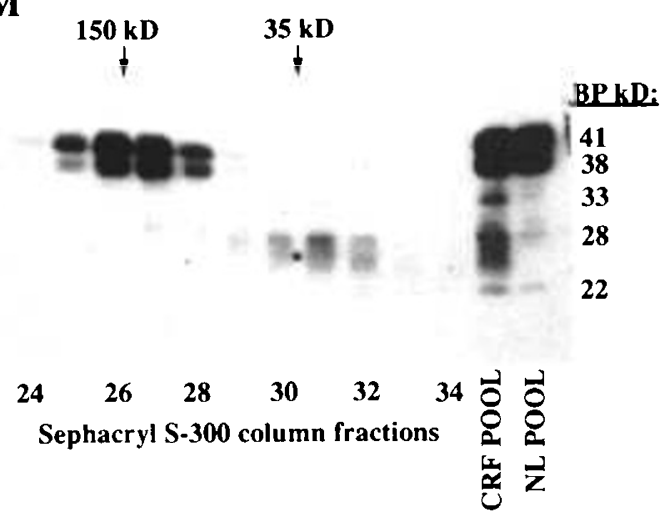

Fig. 4. [25I]IGF-II ligand blot of normal (top) and CRF (bottom) serum fractions after these sera were separated by neutral size-exclusion chromatography. Pooled normal $(N L)$ or CRF sera $(0.5 \mathrm{~mL})$ were separated on a $0.9 \times 120 \mathrm{~cm}$ column of Sephacryl S-300; $2-\mathrm{mL}$ fractions were collected. Unchromatographed pooled serum samples $(2 \mu \mathrm{L})$ or individual column fractions $(30 \mu \mathrm{L})$ were separated by $12 \%$ SDS-PAGE, transferred to nitrocellulose, and probed with [ $\left.{ }^{125} \mathrm{I}\right] \mathrm{IGF}-\mathrm{II}$. Molecular mass estimates of major IGFBP. in $\mathrm{kD}$, are shown beside the [ $\left.{ }^{125} \mathrm{I}\right] \mathrm{IGF}-$ II blots of pooled CRF and NL sera. Individual fractions are numbered below each blot. Protein standards and their peak fractions: thyroglobulin $(669 \mathrm{kD}$; void volume) in fraction 20 ; aldolase $(158 \mathrm{kD})$ in fraction 26 ; recombinant IGFBP-3 (4l and $38 \mathrm{kD}$ ) and ovalbumin ( $43 \mathrm{kD})$ in fraction 29: and myoglobin $(19.5 \mathrm{kD})$ in fraction 33. Estimated elution position of the high-MW serum complex (150 kD) and the low MW IGFBP peak $(35 \mathrm{kD})$ are indicated above each blot.

vestigate the discrepancy between IGFBP-3 levels in CRF serum assayed by ligand blotting and by RIA, equal aliquots of pooled CRF or normal sera were each size-fractionated by neutral gel filtration over a column of Sephacryl S-300, after which individual column fractions were studied for their IGFBP content by ligand blotting. Figure 4 presents the results of a [ $\left.{ }^{125} \mathrm{I}\right] \mathrm{IGF}-\mathrm{II}$ ligand blot of individual CRF and normal-serum fractions. In these experiments, the majority of the 41 - and 38-kDa IGFBP-3 forms in CRF and normal serum coeluted with aldolase at $\sim 150$ $\mathrm{kD}$ in fractions 24 to 29 , with the highest levels present in fraction 26; the $41-$ and $38-\mathrm{kD}$ forms of purified recombinant human
IGFBP-3 eluted from this column significantly later. in fraction 29. CRF and normal sera appeared to have comparable amounts of the 41 - and 38-kD IGFBP-3 forms in these high-MW fractions. In contrast, CRF serum had an excess of low MW, $\sim 35-\mathrm{kD}$ IGFBP, which eluted in fractions 29 to 34; the highest levels were in fraction 31. The IGFBP found in the low-MW fractions include the 33- and 28-kD IGFBP and the diffuse region of [ $\left.{ }^{125} \mathrm{I}\right]$ IGF-II binding between 28 and $22 \mathrm{kD}$, noted previously in CRF serum; these IGFBP were not found in the $150-\mathrm{kD}$ fractions.

Detection of 150-kD Serum Complex by Affinity Cross-Linking. Studies were performed to determine whether IGF peptides, IGFBP-3, and $\alpha$-subunit present in CRF serum could participate in forming the $150-\mathrm{kD}$ serum complex. As shown in Figure 5A, incubating either normal (lane 2) or CRF (lane 3) serum with
A
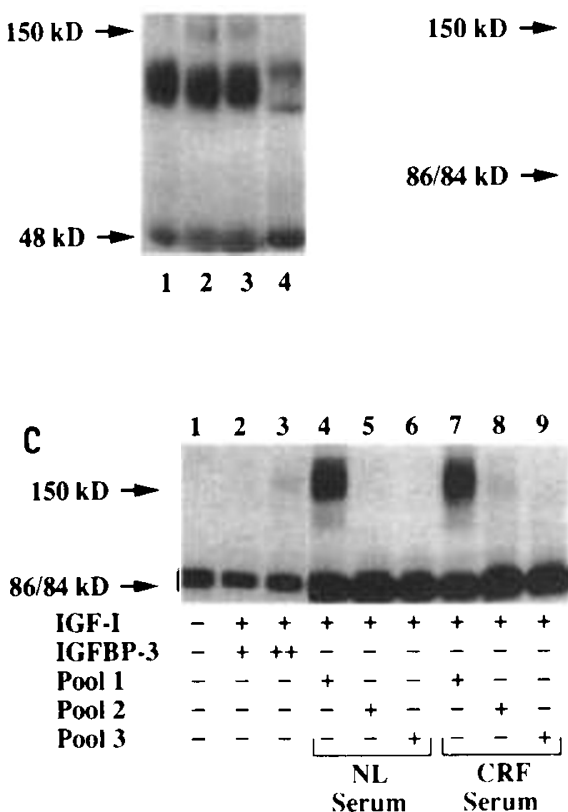

Fig. 5. Detection of reconstructed $150-\mathrm{kD}$ serum complex by affinity cross-linking. $A$, covalently linked $\left[{ }^{125}\right.$ I] IGF-I/IGFBP-3 was incubated with either no additives (lane 1 ), $2 \mu \mathrm{L}$ whole serum pooled from the seven normal adolescents (lane 2), $2 \mu \mathrm{L}$ whole serum pooled from the seven CRF adolescents (lane 3 ), or $2 \mu \mathrm{L}$ pooled normal serum that had first been acidified and then reneutralized (lane 4). Samples were crosslinked and then separated by SDS-PAGE under nonreducing conditions on a 5 to $15 \%$ gradient gel. Bands representing the $150-\mathrm{kD}$ serum complex and the 48-kD [ ${ }^{125}$ I]IGF-l/lGFBP-3 complex are identified on the left by arrows; the intermediate band is likely a nonspecific aggregate of radioligand. $B,\left[{ }^{125} \mathrm{I}\right] \alpha$-subunit was incubated alone or with high-MW (150-kD) or low-MW (35-kD) fractions from neutral Sephacryl S-300 chromatography of normal $(N L)$ or CRF adolescent sera. Fractions 26 and 27 were pooled to form the high-MW (150-kD) fraction, and fractions 30-32 were pooled to form the low-MW (35-kD) fraction: 20 $\mu \mathrm{L}$ of the appropriate pool were in each incubated sample. Samples were cross-linked and then separated under nonreducing conditions by SDSPAGE on a $7.5 \%$ gel. Bands representing the $150-\mathrm{kD}$ serum complex and $86 / 84-\mathrm{kD}$ doublet of $\left[{ }^{125} \mathrm{I}\right] \alpha$-subunit are identified on the left by arrows. $C,\left[{ }^{125} \mathrm{I}\right] \alpha$-subunit was incubated with pure IGF-I and either pure IGFBP-3 or pooled normal $(N L)$ or CRF serum fractions obtained by acid P-60 column chromatography. Acid P-60 column fractions were screened by [ $\left.{ }^{125} \mathrm{I}\right] \mathrm{IGF}-\mathrm{II}$ ligand blot and then pooled to contain primarily IGFBP-3 (pool l), IGFBP-2 and -1 (pool 2), or a 24-kD IGFBP ( pool $3)$. Samples contained either $0(-), 50(+)$, or $100 \mathrm{ng}(++)$ of IGFBP-3 or IGF-I and $0(-)$ or $20 \mu \mathrm{L}(+)$ of pooled acid P- 60 column fractions. Samples were cross-linked and then separated under reducing conditions by SDS-PAGE on a 5 to $15 \%$ gradient gel. Bands representing the 150 $\mathrm{kD}$ serum complex and $86 / 84-\mathrm{kD}$ doublet of $\left[{ }^{125} \mathrm{I}\right] \alpha \cdot$ subunit are identified on the left by arrows. 
[ ${ }^{125}$ I]IGF-I/IGFBP-3 led to formation of a $150-k D$ complex: prior acidification of normal serum (lane 4 ), which destroys $\alpha$-subunit activity, prevented formation of this complex. These results suggest that CRF serum contains functional $\alpha$-subunit. In Figures $5 B$ and $5 C .\left[{ }^{125} \mathrm{I}\right] \alpha$-subunit was used to reconstruct the $150-\mathrm{kD}$ complex. Figure $5 B$ demonstrates the ability of IGF-I and IGFBP-3 present in the high-MW fractions of Sephacryl S-300separated CRF and normal serum to combine with $\left[{ }^{125} \mathrm{I}\right] \alpha$ subunit. The $150-\mathrm{kD}$ complex was seen when high-MW fractions of either normal or CRF serum were incubated with $\left[{ }^{125} I\right] \alpha-$ subunit, whereas the low-MW fractions of normal and CRF serum, which contain IGF and IGFBP but not the 41- and 38$\mathrm{kD}$ forms of IGFBP-3, did not allow formation of this $150-\mathrm{kD}$ complex when incubated with $\left[{ }^{125} \mathrm{I}\right] \alpha$-subunit. Figure $5 C$ confirms that IGFBP-3 from CRF serum can participate in forming the 150-kD complex. Lane $I$ shows the $86 / 84-\mathrm{kD}$ doublet of $\left[{ }^{125} \mathrm{l}\right] \alpha$-subunit, and lane 3 shows that the $150-\mathrm{kD}$ complex can be reconstructed by adding purified IGFBP-3 (100 ng) and IGFI $(50 \mathrm{ng})$. In lanes 4 to 9 , purified IGF-I $(50 \mathrm{ng})$ and [ $\left.{ }^{125} \mathrm{I}\right] \alpha$ subunit were mixed with normal and CRF serum factors collected from an acid P-60 column. Fractions containing the largest amounts of 41- and 38-kD IGFBP-3 forms from normal (lane 4 ) and CRF (lane 7) serum allowed 150-kD complex formation, whereas fractions from normal and CRF serum that contained primarily lower-MW IGFBP but little or no IGFBP-3 (lanes 5 , 6,8 , and 9) did not allow significant amounts of the $150-\mathrm{kD}$ complex to form; clearly, CRF serum contains $41-$ and $38-\mathrm{kD}$ IGFBP-3 forms that participate in forming the $150-\mathrm{kD}$ complex.

RIA of IGFBP and IGF Levels in Size-Fractionated Serum. Individual $\mathrm{CRF}$ and normal serum fractions were assayed for IGFBP-3 by RIA (Fig. 6). Although IGFBP-3 levels in the 150 $\mathrm{kD}$ complex are slightly higher in CRF serum, the greatest difference between CRF and normal samples is found in the lowMW serum fractions, where CRF has a second IGFBP-3 peak that is barely seen in normal serum. This peak could account for the higher IGFBP-3 levels detected in CRF serum by RIA. An IGFBP-1 RIA was performed on these same fractions; IGFBP-1 levels were undetectable in normal serum fractions, but were detectable in fractions 29 to 32 of CRF serum, where they peaked in fraction 31 .

When individual CRF and normal serum fractions were assayed using IGF-I and IGF-II RIA, each IGF had a biphasic

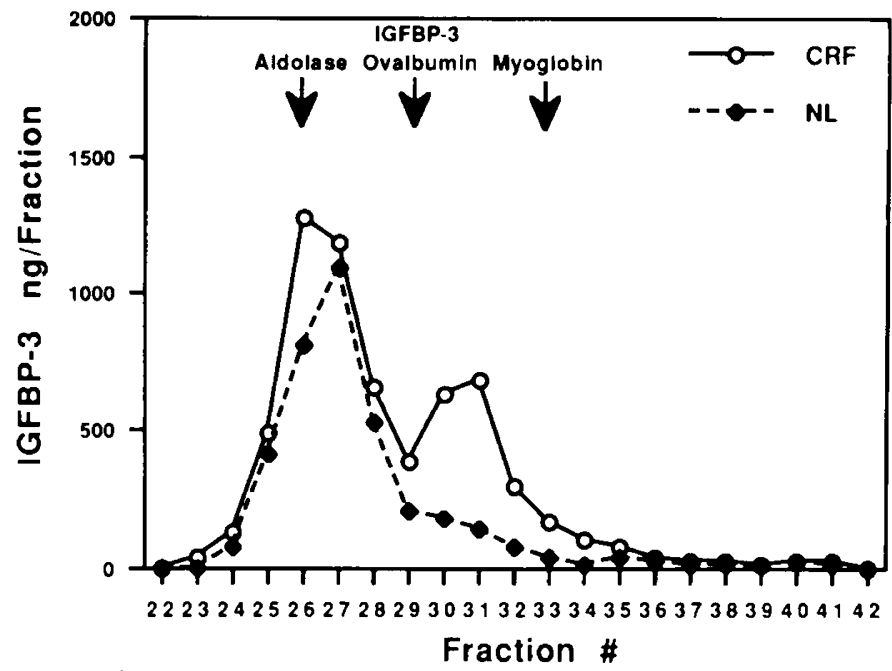

Fig. 6. RIA of IGFBP-3 levels in individual column fractions of sizeseparated normal and CRF serum. The identical Sephacryl S-300 column fractions from chromatographed normal $(N L)$ and CRF sera presented in Figure 4 were assayed for IGFBP-3 by RIA. IGFBP-3 levels are presented on the left as $\mathrm{ng} /$ fraction, with individual column fractions numbered below the graph. Arrows identify fractions containing peak levels of aldolase (158 kD), recombinant IGFBP-3 (4l and $38 \mathrm{kD})$, ovalbumin (43 kD), and myoglobin (19.5 kD). distribution in CRF serum similar to that for IGFBP-3 (data not presented). In normal serum, $86 \%$ of IGF-I and IGF-II were found in the high-MW, 150-kD complex (fractions 24-29.5), with the remaining $14 \%$ in the low-MW size range (fractions $29.5-34)$. In contrast, only $56 \%$ of the IGF peptides were found in the $150-\mathrm{kD}$ complex of CRF serum, with $44 \%$ present in the low-MW size range. Total IGF-I levels were comparable between CRF and normal sera, whereas total IGF-II levels in CRF sera were $30 \%$ higher than normal.

Immunoprecipitation of IGFBP from Size-Separated Serum Samples: Detection by $\left.\right|^{125}$ IJIGF Ligand Blotting. Although lowMW fractions of CRF serum contain a large amount of IGFBP3 by RIA, [ ${ }^{125}$ I]IGF ligand blotting of these same fractions fails to reveal the usual 41- and 38-kD IGFBP-3 forms. To test whether IGFBP-3 forms smaller than 41 and $38 \mathrm{kD}$, perhaps representing proteolytic fragments, were present in these lowMW fractions, volumes of the high- $(150 \mathrm{kD})$ and low- $(35-\mathrm{kD})$ MW IGFBP-3 peaks, which had equal amounts of IGFBP-3 by RIA, were incubated with IGFBP-3 antiserum. This antiserum precipitated the usual 41- and 38-kD IGFBP-3 forms from the high-MW (150-kD) peak, but precipitated barely detectable amounts of the 41- and 38-kD forms and no other IGFBP from the low-MW (35-kD) peak (data not presented). In contrast, IGFBP-2 and IGFBP-1 antisera precipitated their usual 33- and 28-kD IGFBP, respectively, from the low-MW CRF fractions, indicating the integrity of the immunoprecipitation procedure.

Immunoprecipitation of IGFBP from Size-Separated Serum Samples; Detection by I $^{125}$ IIIGF Cross-Linking. In a further attempt to identify low-MW IGFBP-3 forms in CRF serum, the low-MW fractions of pooled CRF and normal sera were crosslinked with [ $\left.{ }^{125} \mathrm{I}\right] \mathrm{IGF}-\mathrm{I}$ and then immunoprecipitated with the antibodies to human IGFBP-3, human IGFBP-1, and rat IGFBP2. As is shown in Figure 7, the IGFBP-3 antiserum precipitated 19- and 14-kD IGFBP (after subtracting the 7-kD mass of the cross-linked IGF-I) from the low-MW fractions of CRF sera; much smaller amounts of these same IGFBP were precipitated from the low-MW fractions of normal sera. IGFBP-1 and IGFBP2 antisera also precipitated more of their usual IGFBP forms from the CRF than from the normal sample; in this experiment. IGFBP-2 was barely detectable in the CRF sample and was not found in the normal sample.

\section{DISCUSSION}

By [ $\left.{ }^{125} \mathrm{I}\right] \mathrm{IGF}$ ligand blot, the concentration and size distribution of the 41- and 38-kD IGFBP-3 forms does not appear to be different between CRF and normal sera from adolescents and children; these IGFBP are primarily found in the $150-\mathrm{kD}$ serum complex in each case (29, present study). The reason for elevated RIA levels of IGFBP-3 in the serum of adolescents with CRF appears to be an excess of IGFBP-3 forms, some or all of which are 19- or 14-kD in size, which circulate at low MW rather than as part of the 150-kD IGF-IGFBP- $\alpha$ subunit complex. Blum $e t$ al. (33) also found elevated RIA levels of IGFBP-3 in the serum of CRF children and determined that part of this increase was due to an RIA peak at $25 \mathrm{kD}$, which was felt to consist of IGFBP3 fragments. In contrast to our past (29) and present studies, however, their study found that intact IGFBP-3 did not migrate at $150-\mathrm{kD}$ during size exclusion chromatography, but instead migrated at $55 \mathrm{kD}$, roughly the size of IGFBP-3 bound to an IGF peptide but without an $\alpha$-subunit. In our studies, Sephacryl S-300 chromatography showed that the 41- and 38-kD IGFBP3 forms of CRF serum migrated with aldolase at $158 \mathrm{kD}$, three fractions ahead of the $41-$ and $38-\mathrm{kD}$ forms of purified human IGFBP-3 (29, present study). In the present work, the 41- and 38-kD forms in CRF sera also comigrated with the same IGFBP3 forms in normal sera, which would be expected if the IGFBP3 forms in CRF sera were part of the typical $150-\mathrm{kD}$ serum complex. Additional studies presented here show that each of the three components of the $150-\mathrm{kD}$ complex (IGFBP-3. IGF, 


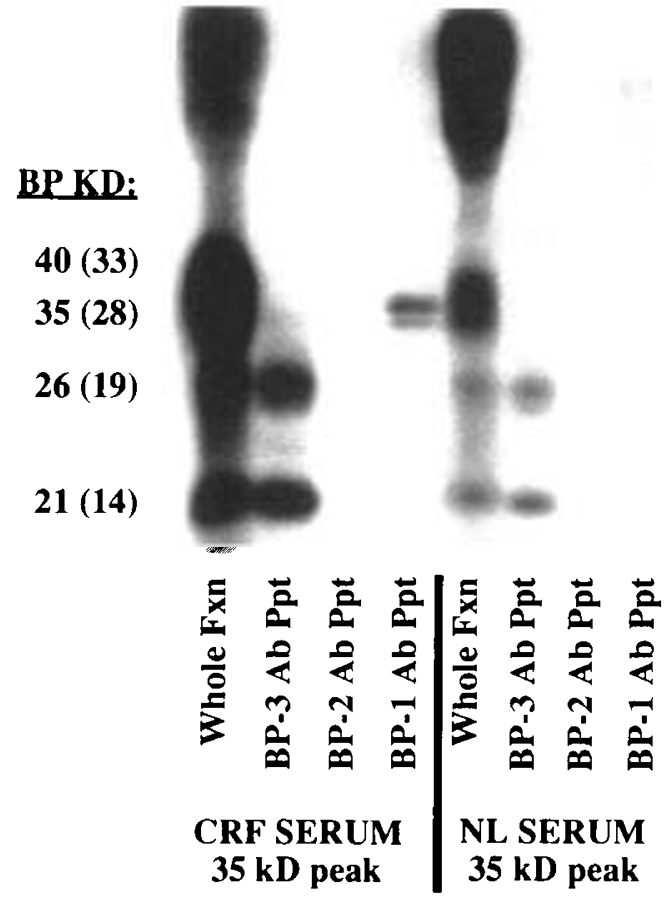

Fig. 7. Immunoprecipitation of IGFBP in the 35-kD (low-MW) column fractions of CRF and normal sera after cross-linking with [ ${ }^{125}$ I]IGFI. IGFBP in the $35-\mathrm{kD}$ fractions of CRF and normal sera were crosslinked with [ $\left.{ }^{125} I\right] I G F-I$ and then either not precipitated or precipitated with specific IGFBP antibodies; samples were separated by $12 \%$ SDSPAGE, transferred to nitrocellulose, and autoradiographed. Equal aliquots of column fractions $30-32$ were pooled for use as the $35-\mathrm{kD}$ (low$\mathrm{MW}$ ) peak of CRF and normal sera. IGFBP in the unprecipitated (whole $F, n$ ) lanes were contained in $20 \mu \mathrm{L}$ of the CRF and normal $(N L)$ pools representing the 35-kD (low-MW) serum peak. IGFBP-3, -2 , and -1 antibodies precipitated IGFBP-3 (BP-3 $A b P p t)$. IGFBP-2 (BP-2 AbPpt), and IGFBP-1 $(B P-I A h P p t)$ from $80 \mu \mathrm{L}$ of the pooled serum fractions representing the CRF and normal $(N L) 35-\mathrm{kD}$ peaks. MW estimates of cross-linked IGFBP. in $\mathrm{kD}$, are on the left; values in parentheses represent the estimated MW of the IGFBP after subtracting the MW of the crosslinked IGF-I ( $7 \mathrm{kD})$.

and $\alpha$-subunit) are present in CRF serum in a form that can be incorporated into this complex. Thus, significant amounts of $150-\mathrm{kD}$ complex seem to be present in the CRF sera studied here. The differences between these observations and those of Blum $e t$ al. may be explained by differences in patients studied; also, if the association between the $\alpha$-subunit and the IGFIGFBP-3 complex is decreased in the $150-\mathrm{kD}$ complex of CRF serum, then the $150-\mathrm{kD}$ complex may remain intact during size separation with Sephacryl S-300 but not with the method used by Blum $e t$ al. Additional studies are needed to characterize both the function of the $150-\mathrm{kD}$ complex and any changes in this complex brought about by exposure to the uremic milieu.

The studies presented here confirm the finding of Blum et al. (33) that higher IGFBP-3 levels in CRF serum are due to accumulation of low-MW IGFBP-3 forms not seen in normal serum. By $\left.{ }^{125} \mathrm{I}\right] \mathrm{IGF}-\mathrm{I}$ cross-linking, they found IGFBP-3 forms of $\sim 45$, $40,30,20$, and $15 \mathrm{kD}$ in CRF serum; they proposed that the 45and $40-\mathrm{kD}$ forms are intact IGFBP-3 that migrated as an $\sim 55$ kD IGFBP-3 peak during size-exclusion chromatography, whereas the 30-, 20-, and 15-kD forms are IGFBP-3 fragments that migrated as an $\sim 25-\mathrm{kD}$ peak. Because their $\sim 25-\mathrm{kD}$ peak is comparable to the $\sim 35-\mathrm{kD}$ RIA peak of IGFBP-3 found in CRF serum in the present study, we cross-linked the IGFBP in this $35-\mathrm{kD}$ peak with [ $\left.{ }^{125} \mathrm{I}\right] \mathrm{IGF}-\mathrm{I}$ and then precipitated with IGFBP3 antiserum to identify the major IGFBP-3 forms present. We found that 19- and 14-kD forms predominated and that intact IGFBP-3 forms were not present, as predicted by Blum et al.
However, the 19- and 14-kD forms may not account for all of the radioimmunoassayable IGFBP-3 in these low-MW fractions of CRF serum, even though they are the major cross-linked IGFBP-3 species in these fractions. The cross-linking method only identified IGFBP-3 forms that bind newly added $\left[{ }^{125} \mathrm{I}\right] \mathrm{IGF}$ $\mathrm{I}$; thus, in addition to the unsaturated 19- and 14-kD forms, the RIA may detect biologically inactive IGFBP-3 fragments as well as biologically active IGFBP-3 species that do not compete for $\left[{ }^{125}\right.$ I]IGF-I binding because they are already bound to other IGF species.

Low-MW IGFBP-3 forms are not the only contributors to the excess of IGFBP in the low-MW fractions of CRF serum: $\left[{ }^{125} \mathrm{I}\right]$ IGF ligand blotting indicates that IGFBP of 33- and 28-kD are in excess in CRF fractions. Immunoprecipitation with specific antisera identifies the 33-kD IGFBP as IGFBP-2 and the 28-kD IGFBP as IGFBP-1. The [ $\left.{ }^{125} \mathrm{I}\right] \mathrm{IGF}$ ligand blots presented here suggest that IGFBP-2 levels in CRF, but not normal, serum contribute significantly to the total IGFBP pool. The finding that CRF adolescents have high serum IGFBP-1 levels by immunoprecipitation and by ligand blot is consistent with high IGFBP-1 levels found in this same serum by RIA and is also consistent with past reports of high RIA levels of IGFBP-1 in serum from CRF children and adults $(19,33,39,40)$. In the present study, IGFBP-1 levels are $1 / 60$ of the levels of IGFBP-3 in serum of CRF adolescents, suggesting that IGFBP-1 does not contribute significantly to the total serum IGFBP pool in adolescents with CRF.

Because CRF serum has an excess of IGFBP relative to IGF peptides, it has been suggested that these excess IGFBP may impair IGF-mediated effects in vivo, including linear growth, and that their excess implies decreased production of IGF peptides $(19,30,33,41)$. Initially, IGFBP-1 was identified as a potential inhibitor of IGF action in CRF (19), but recently it has been suggested that low-MW IGFBP-3 forms are more likely to be inhibitors, inasmuch as their serum RIA levels are much higher than those of IGFBP-1 (33). If IGFBP-3 is a growth inhibitor in CRF children, then IGFBP-3 levels might be expected to fall during therapy, which improves the growth of these individuals. However, although Hokken-Koelega et al. (42) found that serum RIA levels of IGFBP-1 fell in CRF children who grew dramatically during GH therapy, serum RIA levels of IGFBP-3 were found to actually rise in these children. These data are still consistent with a role for IGFBP-3 forms as growth inhibitors if one considers that serum IGF-I levels increased to a greater degree than IGFBP-3 levels in the above study. Thus, a molar excess of IGFBP-3 (and other IGFBP) relative to IGF peptides in the untreated CRF state should result, at equilibrium, in less free IGF-I; in contrast, GH treatment may well decrease the molar excess of IGFBP-3 (and other IGFBP) by increasing the rate of IGF-I production, thereby shifting the equilibrium toward a higher level of free, bioactive IGF-I and limiting the amount of free, unsaturated IGFBP. An alternative explanation is that IGFBP-3 fragments potentiate IGF-I effects and are present in CRF to augment compromised IGF-I function, and that $\mathrm{GH}$ stimulates growth and anabolism in CRF patients, at least in part, by increasing levels of IGFBP-3 fragments. Indeed, this latter possibility is supported by studies showing that IGFBP-3 fragments can potentiate IGF-I action under certain circumstances (43). Unfortunately, neither unsaturated IGFBP levels nor levels of IGFBP-3 fragments were measured by HokkenKoelega et al.

Blum et al. (33) hypothesized that the greater IGF binding capacity of CRF sera, due apparently to excess IGFBP-3 forms, was responsible for the lower incorporation of sulfate into porcine cartilage by these sera. To test this, they first removed unsaturated IGFBP from CRF and normal sera by passing each through an IGF-II affinity column. They then tested the bioactivity of each serum sample and found that sulfate incorporation by CRF sera was closer to normal after removal of unsaturated serum IGFBP, suggesting that excess IGFBP-3 forms in CRF sera inhibit, rather than potentiate, IGF action. The pattern of IGF binding in the 
cross-linking studies presented here suggests that $19-$ and $14-\mathrm{kD}$ IGFBP-3 clearly contribute to the increased IGF binding capacity of CRF serum, but indicate that IGFBP-1 and IGFBP-2 also contribute significantly to this pool of unsaturated IGFBP. These data are consistent with a number of studies that show that excess unsaturated IGFBP, including IGFBP-1, -2 , and -3 , can inhibit IGF-mediated mitogenic and metabolic events in many tissues and cell lines $(15,16,25-28)$. Of particular interest to this discussion is the effect of IGFBP-I on growth plate cartilage; Burch et al. (27) found that purified, unsaturated IGFBP-1 inhibited both basal and IGF-I-mediated growth of chick embryo pelvic cartilage and that the inhibition was overcome with excess IGF-I. In this model, basal cartilage growth was also inhibited with antiserum to human IGF-I, suggesting that IGFBP-1 blocks cartilage growth by competing with the IGF-I receptor for IGF-I binding. The fact that unsaturated IGFBP present in excess in CRF serum can inhibit IGF action is only important if levels of these IGFBP are increased in CRF tissues. Although this has not yet been demonstrated for any IGFBP, past work has shown that IGFBP such as IGFBP-1, IGFBP-2, and a 20-kD form of IGFBP3 readily migrate into lymph fluid (44); thus, these low-MW IGFBP have access to interstitial spaces, and their levels may well be elevated in the tissues of CRF individuals.

The 19- and 14-kD IGFBP-3 proteins present in CRF serum are likely to be proteolytic fragments of the 41 - and $38-\mathrm{kD}$ forms, because only one IGFBP-3 mRNA transcript has been identified and there is only one copy of the IGFBP-3 gene in the human genome $(6,20,45,46)$. In addition, these 19- and 14-kD IGFBP3 forms are similar to proteolytic fragments of IGFBP-3 found in pregnancy serum $(47,48)$. Pregnancy serum contains an enzymatic activity that digests the 41 - and $38-k D$ IGFBP-3 forms present in the $150-\mathrm{kD}$ serum complex, resulting in IGF-binding fragments of 27,19 , and $13 \mathrm{kD}$; purified $41-$ and $38-\mathrm{kD}$ IGFBP3 forms are also digested by this serum activity. The 19- and 13$\mathrm{kD}$ fragments from pregnancy serum are similar to the 19- and 14-kD IGFBP-3 forms in CRF serum in that they are easily detected by [ ${ }^{125}$ I]IGF cross-linking but not ligand blotting (48). It is unlikely that these low-MW IGFBP-3 forms are an artifact of the cross-linking reaction, inasmuch as the 19- and 14-kD forms do not appear when either purified IGFBP-3 or IGFBP-3 released by acid chromatography of the CRF 150-kD complex are cross-linked to IGF peptides $(16,29,48)$. It also seems unlikely that the 19- and 14-kD IGFBP-3 forms accumulate in CRF serum by the same proteolytic process that occurs in pregnancy serum, because CRF serum, unlike pregnancy serum, has normal levels of the 41- and 38-kD IGFBP-3 forms detected by [ ${ }^{125}$ I]IGF-I ligand blotting. Quite possibly, the 19- and 14-kD IGFBP-3 forms accumulate in CRF serum due to decreased renal clearance.

The 19- and 14-kD proteins could be amino- and/or carboxyterminal fragments of IGFBP-3; Spencer et al. (43) isolated a 15$\mathrm{kD}$ IGFBP-3 form that binds IGF and contains the IGFBP-3 amino-terminal sequence, whereas Wang et al. (49) isolated a carboxy-terminal IGFBP-2 fragment that binds IGF. Thus, purification of the 19- and 14-kD IGFBP-3 forms will give insight into where IGFBP-3 proteins bind IGF peptides and will also allow functional studies of these low-MW regulatory proteins that accumulate in CRF serum.

\section{REFERENCES}

1. Froesch ER, Schmid C, Schwander J. Zapf JA 1985 Actions of insulin-like growth factors. Rev Physiol 47:443-467

2. D'Ercole AJ 1987 Somatomedins/insulin-like growth factors and fetal growth. J Dev Physiol 9:481-495

3. Isaksson OGP, Lindahl A. Isgaard J, Nilsson A. Tornell J, Carlsson B 1991 Dual regulation of cartilage growth. In: Spencer EM (ed) Modern Concepts of Insulin-Like Growth Factors. Elsevier, New York, pp 121-127

4. Lee Y-L. Hintz RL. James PM. Lee PDK. Shively JE, Powell DR 1988 Insulinlike growth factor (IGF) binding protein cDNA from human HEP G2 hepatoma cells: predicted protein sequence suggests an IGF binding domain different from those of the IGF-I and IGF-II receptors. Mol Endocrinol 2:404-411
5. Binkert C, Landwehr J, Mary J-L, Schwander J, Heinrich G 1989 Cloning, sequence analysis and expression of a cDNA encoding a novel insulin-like growth factor binding protein (IGFBP-2). EMBO J 8:2497-2502

6. Wood WI, Cachianes G, Henzel WJ, Winslow GA. Spencer SA, Hellmiss R. Martin J, Baxter RC 1988 Cloning and expression of the growth hormonedependent insulin-like growth factor binding protein. Mol Endocrinol 2:1178-1185.

7. Shimaski S, Shimonaka M, Zhang H-P, Ling N 1991 Identification of five different insulin-like growth factor binding proteins (IGFBPs) from adult rat serum and molecular cloning of a novel IGFBP-5 in rat and human. $\mathbf{J} \mathrm{Biol}$ Chem 266:10646-10653

8. Kiefer MC. Ioh RS, Bauer D, Zapf J 1991 Molecular cloning of a new human insulin-like growth factor binding protein. Biochem Biophys Res Commun 176:219-225

9. Kiefer MC, Masiarz FR, Bauer DM, Zapf J 1991 Identification and molecular cloning of two new $30-\mathrm{kDa}$ insulin-like growth factor binding proteins (IGFBPs) isolated from adult human serum. J Biol Chem 266:9043-9049

10. Baxter RC, Martin JL 1989 Binding proteins for the insulin-like growth factors: structure, regulation and function. Prog Growth Factor Res 1:49-68

11. Baxter RC, Martin JL, Beniac VA 1989 High molecular weight insulin-like growth factor binding protein complex. J Biol Chem 264:11843-11848

12. Martin JL, Baxter RC 1986 Insulin-like growth factor-binding proteins from human plasma. J Biol Chem 261:8754-8760

13. Hintz RI, Liu F, Rosenfeld RG, Kemp SF 1981 Plasma somatomedin-binding proteins in hypopituitarism: changes during growth hormone therapy. J Clin Endocrinol Metab 53:100-104

14. Hardouin S. Gourmelen M, Noguiez P. Seurin D. Roghani M, Le Bouc Y. Povoa G, Merimee TJ, Hossenlopp P, Binoux M 1989 Molecular forms of serum insulin-like growth factor (IGF)-binding proteins in man: relationships with growth hormone and IGFs and physiological significance. J Clin Endocrinol Metab 69:1291-1301

15. De Mellow JS, Baxter RC 1988 Growth hormone-dependent insulin-like growth factor (IGF) binding protein both inhibits and potentiates IGF-Istimulated DNA synthesis in human skin fibroblasts. Biochem Biophys Res Commun 156:199-204

16. Conover CA, Ronk M, Lombana F, Powell DR 1990 Structural and biological characterization of bovine insulin-like growth factor binding protein-3. Endocrinology 127:2795-2803

17. Blum WF, Jenne EW, Reppin F, Kietzmann K, Ranke MB, Bierich JR 1989 Insulin-like growth factor I (IGF-I)-binding protein complex is a better mitogen than free IGF-I. Endocrinology 125:766-772

18. Bicsak TA, Shimonaka M, Malkowski M, Ling N 1990 Insulin-like growth factor-binding protein (IGF-BP) inhibition of granulosa cell function: effect on cyclic adenosine $3^{\prime}, 5^{\prime}$-monophosphate, deoxyribonucleic acid synthesis, and comparison with the effect of an IGF-I antibody. Endocrinology 126:2184-2189

19. Lee PDK, Hintz RL, Sperry JB, Baxter RC, Powell DR 1989 IGF binding proteins in growth-retarded children with chronic renal failure. Pediatr Res 26:308-315

20. Liu F, Powell DR, Styne DM, Hintz RL 1991 Insulin-like growth factors (IGFs) and IGF-binding proteins in the developing rhesus monkey. J Clin Endocrinol Metab 72:905-911

21. Hall K, Lundin G. Povoa G 1988 Serum levels of the low molecular weigh form of insulin-like growth factor binding protein in healthy subjects and patients with growth hormone deficiency, acromegaly and anorexia nervosa. Acta Endocrinol (Copenh) 118:321-326

22. Busby WH Jr, Snyder DK, Clemmons DR 1988 Radioimmunoassay of a 26,000-Dalton plasma insulin-like growth factor-binding protein: control by nutritional variables. J Clin Endocrinol Metab 67:1225-1230

23. Unterman TG, Patel K. Mahathre VK, Rajamohan G, Oehler DT, Becker RE 1990 Regulation of low molecular weight insulin-like growth factor binding proteins in experimental diabetes mellitus. Endocrinology 126:2614-2624

24. Ooi GT, Orlowski CC. Brown AL. Becker RE. Unterman TG, Rechler MM 1990 Different tissue distribution and hormonal regulation of messenger RNAs encoding rat insulin-like growth factor-binding proteins- 1 and -2 . Mol Endocrinol 4:321-328

25. Ritvos O, Ranta T, Jalkanen J, Suikkari A-M, Voutilainen R, Bohn H, Rutanen E-M 1988 Insulin-like growth factor (IGF) binding protein from human decidua inhibits the binding and biological action of IGF-I in cultured choriocarcinoma cells. Endocrinology 122:2150-2157

26. Knauer DJ, Smith GL 1980 Inhibition of biological activity of multiplicationstimulating activity by binding to its carrier protein. Proc Natl Acad Sci USA 77:7252-7256

27. Burch WM, Correa J, Shively JE, Powell DR 1990 The 25-kilodalton insulinlike growth factor (IGF)-binding protein inhibits both basal and IGF-Imediated growth of chick embryo pelvic cartilages in vitro. J Clin Endocrino Metab 70:173-180

28. Elgin RG, Busby WH Jr, Clemmons DR 1987 An insulin-like growth factor (IGF) binding protein enhances the biologic response to IGF-I. Proc Nat Acad Sci USA 84:3254-3258

29. Liu F, Powell DR, Hintz RL 1990 Characterization of insulin-like growth factor binding proteins in human serum from patients with chronic renal failure. J Clin Endocrinol Metab 70:620-628

30. Powell DR, Rosenfeld RG, Sperry JB, Baker BK, Hintz RL 1987 Serum concentrations of insulin-like growth factor (IGF)-1, IGF-2, and unsaturated somatomedin carrier proteins in children with chronic renal failure. Am J Kidney Dis 10:287-292 
31. Powell DR, Rosenfeld RG. Baker BK, Liu F. Hintz RL 1986 Serum somatomedin levels in adults with chronic renal failure: the importance of measuring insulin-like growth factor (IGF)-I and IGF-Il in acid-chromatographed uremic serum. J Clin Endocrinol Metab 3:1186-1192

32. Powell DR, Rosenfeld RG. Hintz RL 1988 Effects of growth hormone therapy and malnutrition on the growth of rats with renal failure. Pediatr Nephrol $2: 425-430$

33. Blum WF. Ranke MB. Kietzmann K. Tonshoff B. Mehls O 1991 Growth hormone resistance and inhibition of somatomedin activity by excess of insulin-like growth factor binding protein in uraemia. Pediatr Nephrol 5:539544

34. Baxter RC. Martin JL 1986 Radioimmunoassay of growth hormone-dependent insulinlike growth factor binding protein in human plasma. J Clin Invest $78: 1504-1512$

35. Rutanen E-M. Karkkainen T, Lundquist C. Pekonen F. Ritvos O. Tanner P. Welin M. Weber T 1988 Monoclonal antibodies to the 27- to $34-\mathrm{K}$ insulinlike growth factor binding protein. Biochem Biophys Res Commun 152:208215

36. Yang W-H. Wang J-F. Orlowski CC. Nissley SP. Rechler MM 1989 Structure. specificity. and regulation of the insulin-like growth factor-binding proteins in adult rat serum. Endocrinology 125:1540-1555

37. Blum WF. Ranke MB. Keitzmann K. Gauggel E. Zeisel HJ. Bierich JR 1990 A specific radioimmunoassay for the growth hormone dependent somatomedin binding protein: its use for diagnosis of $\mathrm{GH}$ deficiency. J Clin Endocrinol Metab 70:1292-1298

38. Hossenlopp P. Seurin D. Segovia-Quinson B. Hardouin S. Binoux M 1986 Analysis of serum insulin-like growth factor binding proteins using Western blotting: use of the method for titration of the binding proteins and competitive binding studies. Anal Biochem 154:138-143

39. Drop SLS, Kortleve DJ. Guyda HJ, Posner BI 1984 Immunoassay of a somatomedin-binding protein from human amniotic fluid: levels in fetal, neonatal. and adult sera. J Clin Endocrinol Metab 59:908-915

40. Povoa G Roovete A Hall K 1984 Cross-reaction of serum somatomedinbinding protein in a radioimmunoassay developed for somatomedin-binding protein isolated from human amniotic fluid. Acta Endocrinol 107:563-570

41. Blum WF. Ranke MB. Kietzmann K. Tonshoff B. Mehls O 1989 Excess of
IGF-binding proteins in chronic renal failure: evidence for relative growth hormone resistance and inhibition of somatomedin activity. In: Drop SLS. Hintz RL (eds). Insulin-Like Growth Factor Binding Proteins. Excerpta Medica, Amsterdam, pp 93-101

42. Hokken-Koelega ACS. Stijnen T. de Muinck Keizer-Schrama SMPF. Wit JM. Wolff ED. de Jong MCJW, Donckerwolcke RA, Abbad NCB. Bot A. Blum WF. Drop SLS 1991 Placebo-controlled, double-blind, cross-over trial of growth hormone treatment in prepubertal children with chronic renal failure. Lancet 338:585-590

43. Spencer EM, Steenfos H. Strathearn M. Spratt SK. Hunt TK 1989 Molecular biology and physiology of the insulin-like growth factor binding protein 3 . the acid-stable subunit of the $150 \mathrm{~K}$ serum insulin-like growth factor binding complex. In: Drop SLS, Hintz RL (eds) Insulin-Like Growth Factor Binding Proteins. Excerpta Medica, Amsterdam. pp 73-81

44. Binoux M. Hossenlopp P 1988 Insulin-like growth factor (IGF) and IGFbinding proteins: comparison of human serum and lymph. J Clin Endocrinol Metab 67:509-514

45. Shimasaki S, Koba A. Mercado M. Shimonaka M. Ling N 1989 Complementary DNA structure of the high molecular weight rat insulin-like growth factor binding protein-3 (IGFBP-3) and tissue distribution of its mRNA. Biochem Biophys Res Commun 165:907-912

46. Cubbage ML. Suwanichkul A. Powell DR 1990 Insulin-like growth factor binding protein-3: organization of the human chromosomal gene and demonstration of promoter activity. J Biol Chem 265:12642-12649

47. Hossenlopp. P, Segovia B, Lassarre C, Roghani M, Bredon M, Binoux M 1990 Evidence of enzymatic degradation of insulin-like growth factor-binding proteins in the $150 \mathrm{~K}$ complex during pregnancy. J Clin Endocrinol Metab 71:797-805

48. Guidice LC. Farrell EM. Pham H. Lamson G. Rosenfeld RG 1990 Insulinlike growth factor binding proteins in maternal serum throughout gestation and in the puerperium: effects of a pregnancy-associated serum protease activity. J Clin Endocrinol Metab 71:806-816

49. Wang J.F. Hampton B. Mehlman T. Burgess W. Rechler MM 1988 Isolation of a biologically active fragment from the carboxy terminus of the fetal rat binding protein for insulin-like growth factors. Biochem Biophys Res Commun $157: 718-726$ 